DOI: 10.15587/2312-8372.2017.102151

\section{Buhantsova L., Lushchevska 0. , Troyan 0., Krasniuk L., Yantsalovskyi 0.}

\title{
FORMATION OF THE PACKAGE OF MATERIALS OF ADAPTIVE MULTIFUNCTIONAL CLOTHING
}

У результаті аналітичних та експериментальних досліджень обгрунтовано вибір пакета матеріалів для створення адаптивної білизни для профілактики хронічного простатиту. На основі результатів дослідження товщини швів, у складі яких є засоби лікувально-профілактичного впливу, обрано раціональну технологію виготовлення проектованого виробу. Підтверджено якість та ефективність розробленої адаптивної багатофункціональної білизни шляхом проведення дослідного ношення та клінічної апробації.

Ключові слова: адаптивний багатофункиіональний одяг, товщина шва, енергоінформаційний вплив, пакет матеріалів.

\section{Introduction}

Prospects for development of the clothing industry include the adaptability of products and services, which affects all stages of clothing production. Such promising areas are distinguished in the design of modern clothing [1-3]:

1) synergy of clothing and technologies (technologies of embedding of means (controllers) in clothing, development of textile materials with built-in technologies that provides the end product with extended functions and increased comfort, etc.);

2) development of advanced technologies for the manufacture of materials for clothing (providing protection against temperature drops, antibacterial, antifungal and other properties, protection from ultraviolet light, blocking or radiation of light, etc.);

3) expansion of the clothing functionality, namely:

- reactive - clothing reacts to the characteristics of the environment;

- sensory - clothing when in contact with the body changes the parameters of comfort, in particular air permeability;

- protective - protection from injuries or hazards;

- therapeutic-prophylactic or adaptive - clothing for maintaining of the physical and sensory capabilities of a person in a normal state.

The production of multifunctional clothing combines these directions, with the goal of harmonizing the «man clothing - environment» system on the basis of providing the product with additional functional capabilities aimed at improving the life quality of a modern person.

\section{The object of research and its technological audit}

The object of research is the process of designing of adaptive multifunctional clothing (AMC). Multifunctional clothing promotes human adaptation to changing environmental conditions (climatic, emotional, etc.), so it is adaptive.

One of the most problematic places in the AMC design process is to ensure its effectiveness due to the properties and their energy-information impact on the functional state of the human body.

The human body produces energy of electromagnetic nature, which is formed by the radiation of cells due to the difference in potentials of the cell membrane and intracellular environment. In the cell membrane there are certain protein structures and glycosyl groups associated with the mechanisms of recognition of external influences. These formations are specific cellular receptors that perceive the external effects of the chemical and physical nature, as well as biological fields of ultra-low intensity, such as energy signals. These energy signals exchange information with signals that come from the internal organs, and vice versa. In the case of significant deviations in the frequency-wave characteristics of signals of external influence and frequency-wave characteristics of organs, the activity of the vital functional systems of a person can change. Therefore, the lack of experimental data on the energy and information impact of textile and other materials on the functional state of the human body adversely affects the selection and substantiation of a rational package of materials for AMC manufacturing. To identify the features of this process, medical-biological and psychological approaches are used to determine the adaptive potential of a person. Medical-biological adaptive potential is established for the functional state of the body, it has certain possibilities of adequate response to unfavorable external factors. The psychological approach is the individual psychological characteristics of the individual and the level of compensatory, protective and functional reserves of the human body.

Proceeding from this, the main direction of improving the AMC design process is development and practical application of the principles of AMC conceptual design, based on the use of energy information technologies in the creation of multifunctional clothing.

\section{The aim and objectives of research}

The aim of research is to improve the quality of multifunctional clothing by forming a rational package 
of materials for its manufacture. The main objectives of research are:

1. Selection and substantiation of materials for AMC based on the study of their physico-mechanical properties and energy-information impact on the functional state of the human body.

2. Substantiation of the technology of joining materials and means of AMC influence.

3. Production of experimental AMC, carrying out of its experimental wearing and evaluation of its effectiveness through clinical approbation.

\section{Research of existing solutions of the problem}

Multifunctional clothing is a product or a set of products, which has a wider application for the user due to a combination of basic and additional functions that expand its purpose [2].

The process of conceptual design of multifunctional clothing is based on the following basic principles of [3]:

1) mandatory consideration of user needs, market and fashion trends, as fashion elements in the garment industry are crucial for the psychological and aesthetic comfort of clothing;

2) identification of requirements and needs of consumers regarding the properties of multifunctional products;

3 ) selection of modern materials and technologies that can be used in the design concept;

4) identification of the main factors that are of decisive importance in the development of the concept of multifunctional clothing design;

5 ) evaluation of the concept is a key step in determination of the effectiveness of decisions taken in conceptual design.

The above information indicates the importance of providing a scientifically based approach to the selection of the components of the package of materials in the design of multifunctional clothing.

The use of nanotechnology in the production of modern materials makes it possible to impart new properties of clothing and expand its functionality. Nanomaterials in clothing can provide him with the following properties:

- aesthetics;

- resistance to clotting;

- antimicrobial activity;

- conductivity;

- static electricity protection;

- fire resistance;

- UV protection;

- transfer of medicines; medical and cosmetic;

- water resistance;

- unlawfulness;

- self-cleaning, etc. [4].

At the same time, it is important to ensure the harmonization of the «man-clothing-environment» system, by implementing a choice of environmentally friendly materials and means for expanding the functionality of clothing. In this system, multifunctional clothing is adaptive.

Materials for AMC production and AMC itself can be estimated through the medical and biological adaptive potential of a person, that is, through a quantitative expression of the level of the functional state of the body, preservation of the compensatory and protective properties of the body, psychological characteristics of the personality.

Proceeding from this, according to the authors of the article, when choosing materials for the AMC production, it is important to study their effect on the functional state of the human body.

Today, the transition from a health care system focused on the treatment of diseases to a system based on the priority of a healthy lifestyle, the prevention of diseases and the preservation of human health is urgent. One of the promising areas of new health care system is the wave energy-medicine, the main provisions of which are based on the scientific concept of the importance and the information content of the internal electric fields in the vital processes of the body [6]. The mathematical model of wave processes in the «man-clothing» system is described in work [7], and in the works [8-10] an effective energyinformation component is determined in the development of clothing intended for improvement of the human body.

In energy-information wave medicine, various methods and devices are used to diagnose and test the functional state of the human body. These include the hardwaresoftware diagnostic complex (HSDC) «Intera-DiaCor», which is included in the register of medical equipment of Ukraine (No. 3277/2004 of 30.10.2009). And it is authorized for use in medical practice [11]. This HSDC allows to evaluate the functional state of organs and body as a whole at the cellular level, to monitor the health status and to observe the dynamics of the functional state of the body, organs and systems, to evaluate the effectiveness of health improvement and preventive and curative measures [6, 11].

HSDC is widely used in the AMC designing to determine the energy and information impact of materials and clothing on the functional state of the human body [8, 9, 12] (Fig. 1).

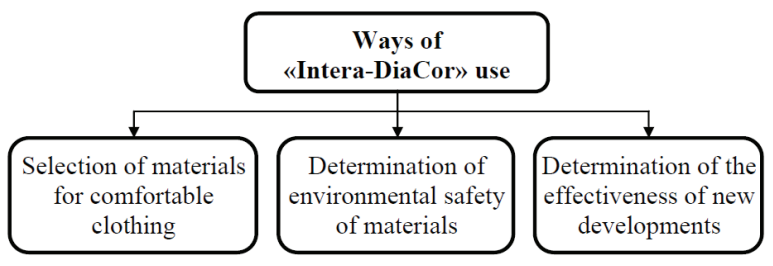

Fig. 1. Ways of use of the hardware-software diagnostic complex «Inter-Diakor» (Ukraine)

According to $[4,8,9,12-16]$, the quality and comfort of AMC significantly depends on the properties of the materials for its manufacture. The AMC package consists of several layers of materials, most often basic, lining and cushioning materials. According to [12], it is important to study the energy-information impact of materials on the functional state of the human body. This will allow choosing inert materials that do not exert excessive positive or negative influence on the body. Inert materials are recommended for use in creating adaptive therapeutic and prophylactic clothing.

Expansion of the AMC functionality, namely providing it with therapeutic and prophylactic properties, provides the use of tools in the form of tabs, sensors, controllers [17-19], medical prophylactic applicators [20].

Analysis of the use of various metals as a means of AMC influence [15, 20, 21], shows that the use of silver 
for the manufacture of means of influence allows to provide energy-information impact on the functional state of the human body and improve the hygienic properties of the product.

Placement of these means must correspond to the biologically active zones (BAZ) of the human body, which have a reflex connection with internal organs and systems of the body. Local impact of such means on certain BAZ of the body produces reactions of organs and organ systems that can restore their normal functioning [6, 11, 21].

Significant factors affecting the AMC efficiency and its therapeutic and prophylactic properties is the thickness of the package of materials [22, 23]. The value of this indicator is influenced by the number of layers of materials, the method of joining, the type of seams, the chosen means of influence, etc.

The joining of AMC materials is most often used in a thread-like manner, so ensuring the quality of the threaded seams is an important issue regarding the AMC quality and comfort. The parameters affecting the quality of the threaded seams are the seam strength, its elongation, the seam stiffness when bending, etc. [24-27].

When analyzing the structure of the threated seam, the following parameters are taken into account:

- number of layers of the main material;

- number of lining layers;

- number of folds in the seam;

- number of stitches in the seam [23];

- seam thickness and the coefficient of seam thickness [28];

- thickness of materials included in the seam package, according to DSTU 3998-2000.

Quality indicators of threaded seams are most often assessed by the ratio of the seam thickness and the joint material thickness. In [28], the seam thickness $\left(\tau_{s}\right)$ is calculated as the total thickness of the top materials $\left(\tau_{m j}\right)$, taking into account the size of the layers between all layers of materials. In this case, the main evaluation index is the seam thickness coefficient $\left(K_{s t}\right)$, which is the ratio of the seam thickness at the seam location to the total value of the calculated thickness of the package of materials in the seam [28]:

$$
K_{s t}=\frac{\tau_{s}}{\sum_{j=1}^{n_{j}} \tau_{m j}},
$$

where $j$ - the serial number of the material; $n_{j}-$ the number of layers of the material.

The author [28] determined that for the same types of joints of the same group of materials, the values of the seam thickness coefficient are the same. Therefore, according to this indicator, based on the values of the thickness of the joining materials and the means of action, it is possible to obtain the predicted value of the thickness of the clothing seams. This will make it possible to reasonably carry out the choice of materials and technology of connecting the means of influence, even at the stage of AMC conceptual design to ensure its comfort in operation.

So, AMC must provide its basic and additional advanced functions, be made of environmentally friendly materials and effective means of influence on rational technology, have an ergonomic design, has a predictable effect on the functional state of the human body. That is why AMC quality improvement based on a rational choice of a package of materials for its manufacture is a promising direction of modern research.

\section{Methods of research}

5.1. The concept of research, investigated materials in the experiment. On the basis of the principles of conceptual design of multifunctional clothing stated earlier for the rational formation of a package of materials for AMC, the development of a technology for its production and the evaluation of design solutions, the authors of the article developed the scheme shown in Fig. 2.

The AMC quality improvement, first of all, is realized by defining the design situation, the main and additional functions of the clothing. Proceeding from this, it is important to choose and justify the materials and means of influencing the BAZ of the human body, because this information is the basis for the substantiation of the technology of combining the elements of clothing (materials and means of influence). The next stage in AMC conceptual designing is the manufacture of a prototype product, including the choice of the BAZ of the body, construction of the product design and development of technology for its manufacture. Evaluation of AMC effectiveness is performed on experimental wearing and the results of clinical approbation (Fig. 2).

According to the principles of AMC conceptual designing, the authors develop therapeutic and preventive underwear - men's underpants. Expansion of the product functions is the treatment and prevention of urological diseases, in particular chronic prostatitis, which is justified by the urgency of treatment and prevention of prostatic diseases in men.

For the manufacture of men's underwear, knitted fabrics are selected (Table 1 ).

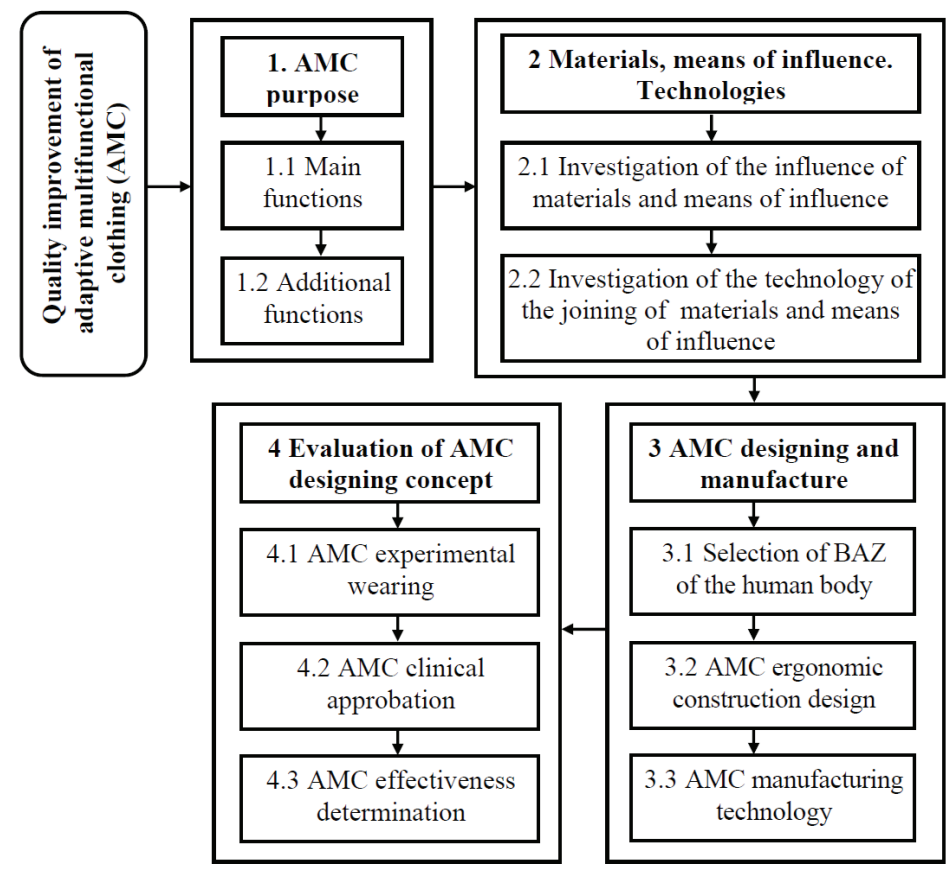

Fig. 2. The scheme of conceptual designing of adaptive multifunctional clothing 
Structural and physical-mechanical characteristics of knitted fabrics for making men's underwear

\begin{tabular}{|c|c|c|c|c|c|}
\hline $\begin{array}{c}\text { Designation of } \\
\text { knitted fabric }\end{array}$ & $\begin{array}{c}\text { Raw material } \\
\text { composition, } \%\end{array}$ & $\begin{array}{c}\text { Thickness, mm } \\
\text { G05T 12023-2003 }\end{array}$ & $\begin{array}{c}\text { Surface density, g/m } \\
\text { DSTU EN 12127:2009 }\end{array}$ & $\begin{array}{c}\text { Hygroscopicity, \% } \\
\text { DSTU G05T 3816:2009 }\end{array}$ & $\begin{array}{c}\text { Humidity, \% } \\
\text { G05T 8845-87 }\end{array}$ \\
\hline T1 & $\begin{array}{c}\text { Viscose - 97 } \\
\text { Elastane - 3 }\end{array}$ & 0.45 & 146.0 & 23.0 & 5.47 \\
\hline T2 & Cotton - 100 & 0.70 & 212.4 & 17.35 & 6.61 \\
\hline T3 & Cotton - 100 & 0.64 & 185.0 & 20.0 & 6.79 \\
\hline T4 & $\begin{array}{c}\text { Viscose - 92 } \\
\text { Elastane - 8 }\end{array}$ & 0.65 & 188.2 & 16.0 & 3.79 \\
\hline T5 & $\begin{array}{c}\text { Cotton - 97 } \\
\text { Elastane - 3 }\end{array}$ & 0.31 & 116.0 & 20.35 & 3.99 \\
\hline
\end{tabular}

The therapeutic and prophylactic effect of AMC is provided by the use of means of action in the form of silver plates containing medical information. Silver plates of round shape, diameter $-5 \mathrm{~mm}$ and thickness $-0.4 \mathrm{~mm}$ are located between the layers of the lining and the main material of the product in places that are projections of the corresponding BAZ of the human body.

5.2. Equipment and method for determination of the indicators of properties. Evaluation of the energy-information impact of knitted fabrics on the functional state of the human body is performed using HSDC «InteraDiaCor». HSDC «Intera-DiaCor» consists of a device for electropuncture diagnostics (EPD) (Fig. 3) and software installed on a personal computer (PC).

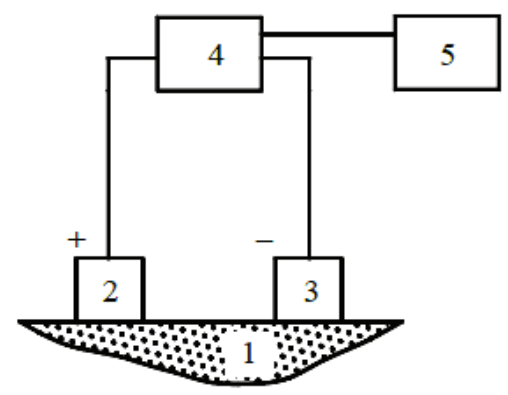

Fig. 3. The scheme of the hardware-software diagnostic complex «Intera-DiaLor» (Ukraine): 1 - human skin; 2 - «active» electrode; 3 - "passive» electrode; 4 - device for electropuncture diagnostics; 5 - personal computer

The method of the study is as follows (Fig. 3): on the skin areas (1) of the palms, feet and face of the person fix the «active» $(2)$ and «passive» $(3)$ electrodes. Through the electrodes from the device for the EPD (4), electrical impulses are applied to the skin areas (1), and they also register the frequency-wave characteristics of organs and organ systems. Information from the device for EPD is transmitted to the PC (5), where the data is processed using the software HSDC «Intera-DiaCor», which allows to get a diagnosis of the functional state of the human body. After that, a sample of investigated knitted fabric is introduced into the contour of the «passive» electrode and the frequency-wave characteristics of the organs and systems of the human body are repeatedly recorded with the influence of investigated sample.

After two complete cycles of diagnosis, the results of the diagnosis of the functional state of organs and systems of the human body are compared without affecting the knitted fabric and with it. At the same time, the histograms that reflect the three basic conditions of the organs and systems of the human body are compared on the PC monitor:

- energy lability (upper histogram columns);

- energy instability (middle histogram columns);

- energy insufficiency (bottom histogram columns).

Energy lability is the norm and reflects the relatively stable energy processes of organs and systems. Energy instability indicates instability and the tension of the energy processes. According to energy insufficiency, it indicates the depression of the energy processes of organs and systems, which leads to the depletion of the functional state of the human body.

In this case, the higher the column height, the better the energy and functional state of the organ.

The level of negative and positive energy-information impact of the knitted fabric on the human body, as well as its inertness, is evaluated by the numerical values of the coefficients $K_{N}, K_{P}$, and $K_{i}$, respectively:

$$
\begin{aligned}
& k_{N}=K_{N} / K_{D}, \\
& k_{P}=K_{P} / K_{D}, \\
& k=K_{I} / K_{D}, \\
& k_{N}+k_{P}+k_{I}=1,
\end{aligned}
$$

where $K_{N}$ - the number of organs (systems of organs) of the human body, in the functional state of which there were negative changes, caused by the influence of investigated knit fabric; $K_{P}$ - the number of organs of the human body, in the functional state of which there were positive changes caused by the influence of the knitted fabric; $K_{I}$ - the number of organs of the human body, in the functional state of which there was no change in the impact of investigated knitted fabric; $K_{D}$ - the number of diagnosed organs of the human body.

The mathematical notation of formulas (2)-(4) for calculating the levels of negative and positive energyinformation impact of a knitted fabric on a human body, as well as its inertness, reflects a relative evaluation of the reaction of the human body to investigated materials.

The choice of materials and means of influence for AMC is accompanied by a justification of the technology of its manufacture. To provide AMC with predicted additional functions, patches and means of influence are used, the connections of which with the base material are 
performed by overlaid seams (seams of classes 2 and 5, respectively, DSTU ISO 4916:2005). The standard method in accordance with GOST 12023-2003 is used for determination the thickness of materials, means of influence and the seam thickness.

To experimental wearing of the developed AMC, questionnaires of psycho-physiological sensation of a person in the product have been used and indicators of operational control of standard methods have been determined. Arterial pressure and heart rate are determined by the automatic tonometer BP-3BTO-AP (Microlife Medical Science Asia Ltd, Taiwan) with the system of accuracy control (Fuzzy Logic).

\section{Research results}

To select an inert knit fabric, the level of its negative, positive and inert influence on the functional state of the human body is studied (Table 2). The study was carried out for ten persons, which functional state of the body at the time of the study did not have significant deviations from the norm. Such quantity is sufficient, as definition of the functional condition of the human body with the help of HSDC «Intera-DiaCor» differs high accuracy (relative guarantee error does not exceed $5 \%$ ).

It is established that all knitted fabrics have an energyinformation impact on the human body. Considering the purpose of knitted fabrics, it is important to choose fabrics with high inertness coefficients for the functional state of the body (Table 3). recommended as the main material for the manufacture of adaptive therapeutic and prophylactic clothing.

Table 3

Analysis of the investigation results of inertness level of knitted fabrics for the functional state of the human body

\begin{tabular}{|c|c|c|c|c|c|}
\hline \multirow{2}{*}{$\begin{array}{c}\text { Coefficient } \\
\text { value } k_{I}\end{array}$} & \multicolumn{5}{|c|}{$\begin{array}{c}\text { Percentage distribution of the number of human subjects } \\
\text { according to inertness level of knitted fabric samples, \% }\end{array}$} \\
\cline { 2 - 6 } & $\mathrm{T} 1$ & $\mathrm{~T} 2$ & $\mathrm{~T} 3$ & $\mathrm{~T} 4$ & $\mathrm{~T} 5$ \\
\hline $0.95 \ldots 1.00$ & 40 & 40 & 30 & 40 & 70 \\
\hline $0.90 \ldots .0 .94$ & 40 & 20 & 10 & 30 & 20 \\
\hline $0.85 \ldots 0.89$ & 10 & 30 & 10 & 30 & 10 \\
\hline $0.80 \ldots 0.84$ & 10 & - & 10 & - & - \\
\hline $0.75 \ldots .0 .79$ & - & 10 & 20 & - & - \\
\hline $0.70 \ldots .0 .74$ & - & - & 10 & - & - \\
\hline less 0.7 & - & - & 10 & - & - \\
\hline
\end{tabular}

To select a rational AMC package of materials and the technology of their joining, the thickness of the overlaid seams is investigated. The seams have the following parameters:

- number of layers of the main material $\left(n_{j}=1\right)$;

- number of lining layers $\left(n_{\gamma}=1, n_{\gamma}=2\right)$;

- number of stitches in the seam $\left(n_{s}=1, n_{s}=2\right)$

- number of silver plates $\left(n_{i}=1\right)$ (Fig. 4).

Table 2

The results of calculation of energy-information impact level of the knitted fabrics on the human body

\begin{tabular}{|c|c|c|c|c|c|c|c|c|c|c|c|c|c|c|c|}
\hline \multirow{3}{*}{$\begin{array}{c}\text { Number } \\
\text { of per- } \\
\text { son }\end{array}$} & \multicolumn{15}{|c|}{$\begin{array}{l}\text { The level of energy-information impact of a knitted fabric sample } \\
\text { on the functional state of the human body: }\end{array}$} \\
\hline & \multicolumn{5}{|c|}{ Negative $\left(k_{N}\right)$} & \multicolumn{5}{|c|}{ Positive $\left(k_{P}\right)$} & \multicolumn{5}{|c|}{ Inert $\left(k_{I}\right)$} \\
\hline & T1 & T2 & T3 & T4 & $\mathrm{T} 5$ & T1 & T2 & $\mathrm{T} 3$ & T4 & T5 & T1 & T2 & T3 & $\mathrm{T} 4$ & T5 \\
\hline 1 & 0.06 & 0 & 0 & 0.03 & 0.02 & 0.03 & 0.07 & 0.12 & 0.03 & 0.03 & 0.91 & 0.93 & 0.88 & 0.94 & 0.95 \\
\hline 2 & 0 & 0 & 0.02 & 0 & 0 & 0 & 0.03 & 0.02 & 0.03 & 0 & 1.00 & 0.97 & 0.96 & 0.97 & 1.00 \\
\hline 3 & 0 & 0.02 & 0.02 & 0 & 0 & 0.08 & 0.03 & 0.02 & 0.06 & 0.02 & 0.92 & 0.95 & 0.96 & 0.94 & 0.98 \\
\hline 4 & 0.05 & 0 & 0 & 0.05 & 0 & 0.06 & 0.05 & 0.24 & 0.06 & 0.08 & 0.89 & 0.95 & 0.76 & 0.89 & 0.92 \\
\hline 5 & 0.06 & 0.07 & 0.12 & 0.04 & 0.05 & 0.02 & 0.07 & 0.13 & 0.02 & 0 & 0.92 & 0.86 & 0.75 & 0.94 & 0.95 \\
\hline 6 & 0.02 & 0 & 0.02 & 0.03 & 0.04 & 0.15 & 0.09 & 0.18 & 0.12 & 0.02 & 0.83 & 0.91 & 0.80 & 0.85 & 0.94 \\
\hline 7 & 0.03 & 0 & 0 & 0.03 & 0.03 & 0 & 0.13 & 0.04 & 0 & 0.02 & 0.97 & 0.87 & 0.96 & 0.97 & 0.95 \\
\hline 8 & 0 & 0.03 & 0.21 & 0 & 0.02 & 0.03 & 0.02 & 0.15 & 0.04 & 0.02 & 0.97 & 0.95 & 0.64 & 0.96 & 0.96 \\
\hline 9 & 0.02 & 0 & 0.05 & 0.03 & 0.02 & 0.03 & 0.13 & 0.05 & 0.02 & 0.02 & 0.95 & 0.87 & 0.90 & 0.95 & 0.96 \\
\hline 10 & 0 & 0.02 & 0.03 & 0 & 0 & 0.07 & 0.20 & 0.25 & 0.13 & 0.12 & 0.93 & 0.78 & \begin{tabular}{|l|l|} 
\\
\end{tabular} & 0.87 & 0.88 \\
\hline
\end{tabular}
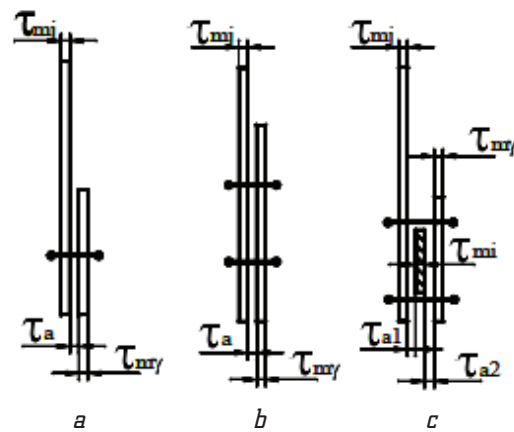

Fig. 4. Images of overlaid seams: $a-\operatorname{seam} 1\left(n_{j}=1, n_{\gamma}=1, n_{s}=1\right) ;$ $b-\operatorname{seam} 2\left(n_{j}=1, n_{\gamma}=1, n_{s}=2\right) ;$ $c-\operatorname{seam} 3\left(n_{j}=1, n_{\gamma}=1, n_{s}=2, n_{i}=1\right)$; $\tau_{m j}$ - thickness of the j-th layer of the basic material; $\tau_{\text {mr }}$ - thickness of the $\gamma$-th layer of the lining; $\tau_{m i}$ - thickness of the i-th layer of the plate; $\tau_{a 1}$ and $\tau_{a 2}$ - respectively, the thickness of the 1st and 2nd air layer
Analysis of investigation results of inertness level of knitted fabrics made it possible to establish that a high inertness level $\left(k_{I}=0.95 \ldots 1.00\right)$ for the functional state of the body of $70 \%$ of individuals has a pattern of knitted fabric T5. Since this fabric has the smallest thickness $(0.31 \mathrm{~mm})$ and a high inertness, it is selected as a lining material for manufacturing of the projected AMC. Also high values of $k_{I}$ have samples of knitted fabrics T4 $\left(k_{I}=\right.$ $=0.87 \ldots 0.97)$ and $\mathrm{T} 1\left(k_{I}=0.83 \ldots 1.00\right)$. This inertness level indicates that there is no excessive positive or negative energy-information effect of fabric on the state of organs and systems of the human body. That is why they are
The investigation results of the thickness of materials that are included in the AMC package and the calculation of the seam thickness coefficient (1) are presented in Table 4.

In order to compare the thickness of the package of materials, a diagram is plotted on the joining section of the AMC elements (Fig. 5).

Analysis shows that the main components of the thickness of the AMC package of material are single indicators: base material thickness (within 26.7...53.03\% of the thickness of the entire package) and silver plate thickness $(32 \%)$. 
The investigation results of seam thickness for AMC joining elements

\begin{tabular}{|c|c|c|c|c|c|c|c|c|c|c|c|c|}
\hline \multirow{2}{*}{$\begin{array}{l}\text { Designa- } \\
\text { tion of } \\
\text { material }\end{array}$} & \multirow{2}{*}{$\begin{array}{l}\text { Base mate- } \\
\text { rial thick- } \\
\text { ness, mm }\end{array}$} & \multirow{2}{*}{$\begin{array}{l}\text { Lining } \\
\text { thickness, } \\
\text { mm }\end{array}$} & \multirow{2}{*}{$\begin{array}{l}\text { Silver } \\
\text { plate thick- } \\
\text { ness, mm }\end{array}$} & \multicolumn{3}{|c|}{ Seam thickness $\tau_{s,} \mathrm{~mm}$} & \multicolumn{3}{|c|}{$\begin{array}{l}\text { Estimated value of the thickness } \\
\text { of materials in the seam } \sum_{j=1}^{n_{j}} \tau_{m j} \text {, mm }\end{array}$} & \multicolumn{3}{|c|}{$\begin{array}{l}\text { Seam thickness } \\
\text { coefficient, } K_{S T}\end{array}$} \\
\hline & & & & seam 1 & seam 2 & seam 3 & seam 1 & seam 2 & seam 3 & seam 1 & seam 2 & seam 3 \\
\hline $\mathrm{T} 1$ & 0.45 & 0.31 & 0.4 & 0.80 & 0.83 & 1.25 & 0.76 & 0.76 & 1.16 & 1.05 & 1.09 & 1.08 \\
\hline $\mathrm{T} 2$ & 0.70 & 0.31 & 0.4 & 1.00 & 1.04 & 1.45 & 1.01 & 1.01 & 1.41 & 0.99 & 1.03 & 1.03 \\
\hline T3 & 0.64 & 0.31 & 0.4 & 0.98 & 1.00 & 1.45 & 0.95 & 0.95 & 1.35 & 1.03 & 1.05 & 1.07 \\
\hline $\mathrm{T} 4$ & 0.65 & 0.31 & 0.4 & 0.96 & 0.94 & 1.32 & 0.96 & 0.96 & 1.36 & 1.00 & 0.98 & 0.97 \\
\hline T5 & 0.31 & 0.31 & 0.4 & 0.68 & 0.72 & 1.16 & 0.62 & 0.62 & 1.02 & 1.10 & 1.16 & 1.14 \\
\hline
\end{tabular}

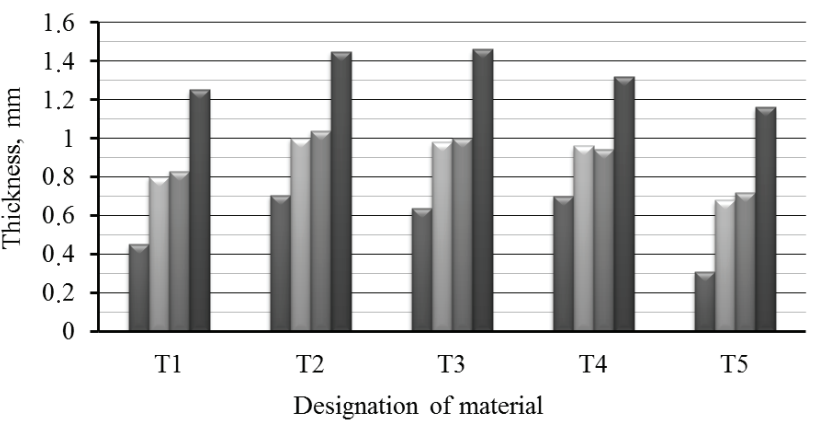

$\square$ base materials (without seam) $\square$ seam $1 \square$ seam $2 \square$ seam 3

Fig. 5. A diagram for comparison of the thickness of the AMC package of materials and seams

When joining the layers of AMC parts, they are collected by thread lines. Since the silver plates are inserted between the materials after the stitching, the materials are stretched, and as a result, seam thickness of the package of materials is increased by $28.2 \ldots .37 .9 \%$. The above is confirmed by the photographic images of the seams in a section (Fig. 6).
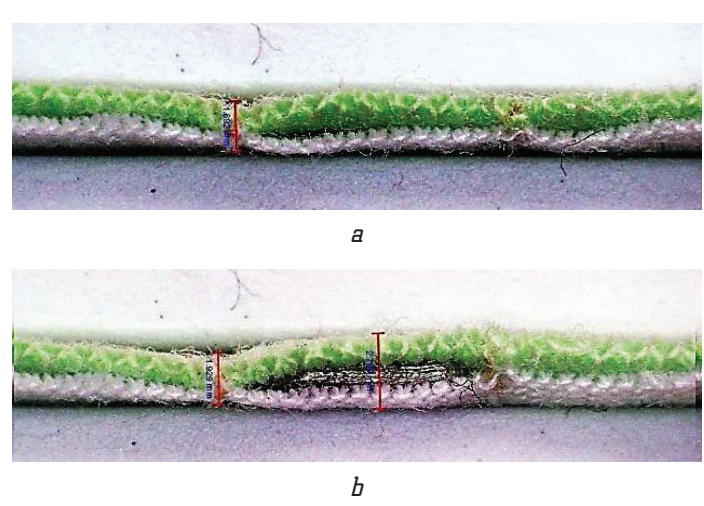

Fig. 6. Photographs of overlaid seams in a section (material T4): $a$ - without a silver plate (seam 2); $b$ - with a silver plate (seam 3)

Research results confirm that the seam thickness coefficient is an adequate indicator of quality evaluation of the seams, since its value is most affected by the base material thickness (Fig. 7) and the silver plate thickness (Fig. 8).

It should be noted that when choosing materials for $\mathrm{AMC}$ and the technology of its manufacture, it is expedient to determine the value of the calculated thickness of the package of materials in the seam. For this reason, the dependence of the seam thickness coefficient on this index is established (Fig. 9).

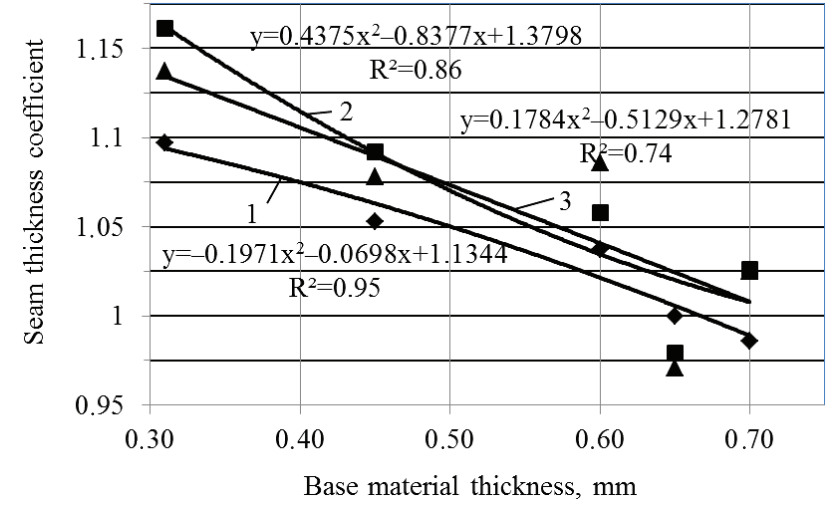

Fig. 7. Dependence of the seam thickness coefficient on the base material thickness: $1-\operatorname{seam} 1 ; 2-\operatorname{seam} 2 ; 3-\operatorname{seam} 3$

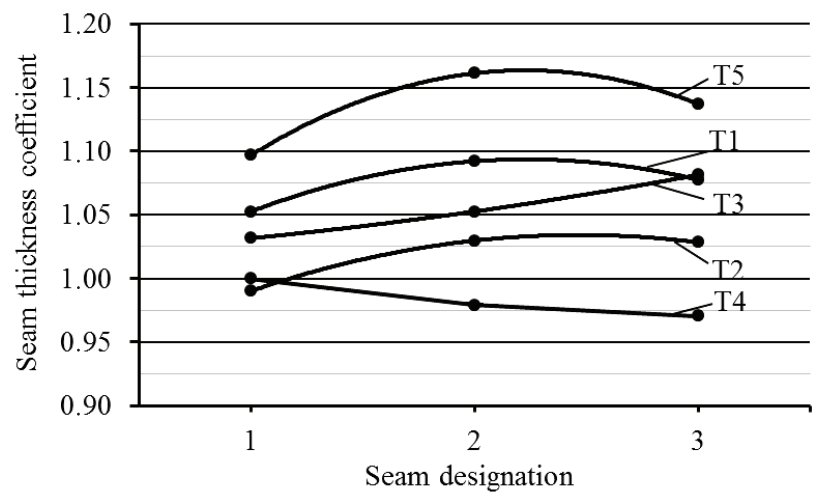

Fig. 8. Change in the seam thickness coefficient for seams: $1-\operatorname{seam} 1 ; 2-\operatorname{seam} 2 ; 3-\operatorname{seam} 3$

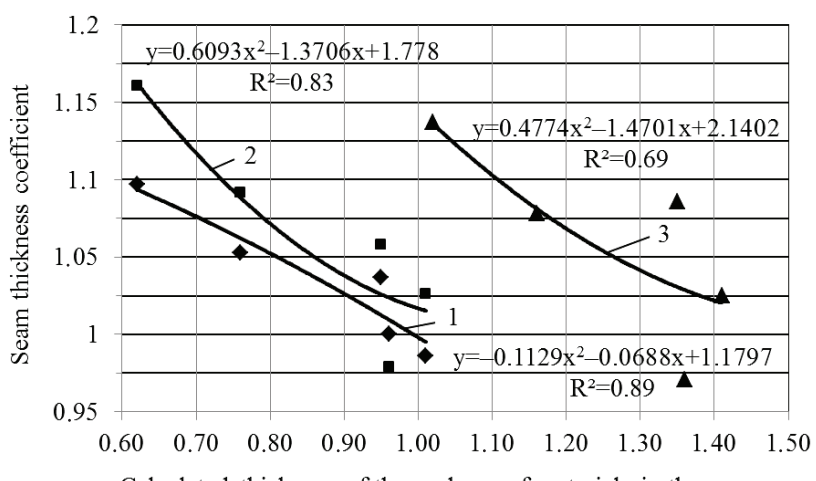

Calculated thickness of the package of materials in the seam

Fig. 9. Dependence of the seam thickness coefficient on the calculated thickness of the package of materials in the seam: $1-\operatorname{seam} 1 ; 2-\operatorname{seam} 2 ; 3-\operatorname{seam} 3$ 
Analysis of research results made it possible to choose a knitted fabric T4 for the manufacture of therapeutic and prophylactic clothing. This is explained by the fact that among the five samples, an increase in the seam thickness (seam 3) for material T4 is the least - by $28.8 \%$. In addition, the selected material has the lowest value of the seam thickness coefficient -0.97 .

Thus, on the principles of AMC conceptual designing, men's medical and preventive underpants are designed and manufactured, the appearance of which is shown in Fig. 10.
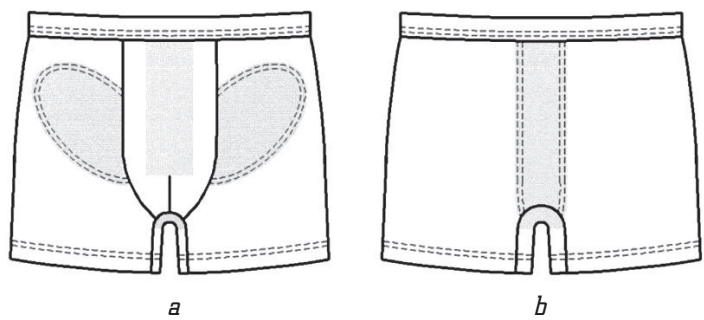

Fig. 10. Appearance of men's medical and preventive underpants: $a-$ front view; $b$ - back view. Note: gray color indicates the location of the overlays with silver plates

The therapeutic and prophylactic effect of men's underpants is ensured by silver plates located on the clothing sites contacting the BAZ with a close fit of the product to the lower part of the human body (Fig. 11).

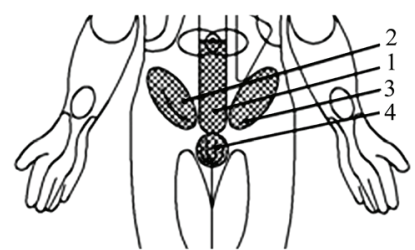

a

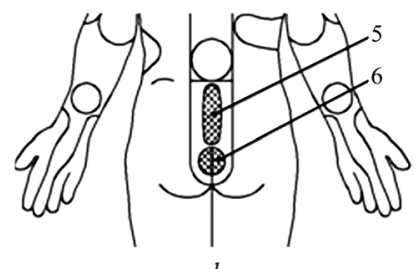

b
Fig. 11. BAZ location for treatment and prevention of chronic prostatitis: $a-$ front view; $b$ - back view

The patterns of linings with locations of the silver plates are developed for the manufacture of the therapeutic and prophylactic underpants. To ensure the therapeutic and prophylactic effect of the men's underwear, the distance between the centers of the silver plates is taken to be $30 \mathrm{~mm}$, which makes it possible to achieve a uniform effect on the entire BAZ surface.

It is found that silver plates are intangible during AMC operation, that is, do not cause discomfort for the consumer and do not deform during the operation of the product. This is confirmed by the results of experimental wearing of created AMC, in which 10 people took part. Each of them used the clothing for an hour. By the beginning of the experimental wearing of the developed clothing and after its completion, the indicators of operational control are determined. Psychophysiological sensations of a person in AMC are evaluated according to the following criteria:

- convenience in movements (seats, sit-ups, walking);

- self-estimation of the functional state of the body;

- comfort in the clothing;

- thermal sensations in the clothing.

According to the results of experimental wearing it is found that blood pressure, heart rate and self-estimation of the functional state of all persons do not deteriorate during the use of clothing. In addition, developed men's therapeutic and prophylactic underpants do not create uncomfortable sensations in motion. The persons who exploited it $(100 \%)$ note that the underwear is highly comfortable and pleasant in terms of warmth.

The effectiveness of the developed underwear is assessed by clinical approbation of medical and preventive underpants in Khmelnytsky city polyclinic № 4 (Ukraine) for ten patients, with chronic prostatitis with seasonal exacerbation in autumn. The duration of the disease lasted from five to seven years. The age of the patients ranged from twenty-one to forty-four years.

All patients underwent general clinical laboratory tests: general blood analysis with leukogram, general urine analysis, blood sugar analysis, prostate secretion analysis and ultrasound examination. In addition to the general clinical laboratory and apparatus methods, the patients underwent a study of the functional state of the body, in particular the genitourinary system, with the help of HSDC «InteraDiaCor».

As a result of clinical examination, nine patients out of ten found a latent (subclinical) exacerbation of chronic prostatitis, which at the time of the examination was not accompanied by the manifest symptoms characteristic of this disease. One patient showed the onset of exacerbation of the disease, accompanied by clinical signs, in particular: pain, dysuric syndromes and erectile dysfunction.

All examined patients are recommended to wear the developed therapeutic and prophylactic underwear (underpants). This underwear is intended to be worn for one month for two hours a day during the period of the highest activity of the bladder channel (from 15 to 17 hours). A patient with clinical manifestations of chronic prostatitis is prescribed a course of treatment according to clinical protocols from urology, and it is recommended to wear the specified underwear according to the method described above.

In a month, all the patients underwent a control study: general clinical laboratory tests, laboratory study of the secretion of the prostate gland, examination with ultrasound and HSDC «Intera-DiaCor».

Fig. 12 shows the window of HSDC «Intera-DiaCor», which reflects the comparison of the diagnostics results of the functional state of the body without the influence of the developed AMC and with it.

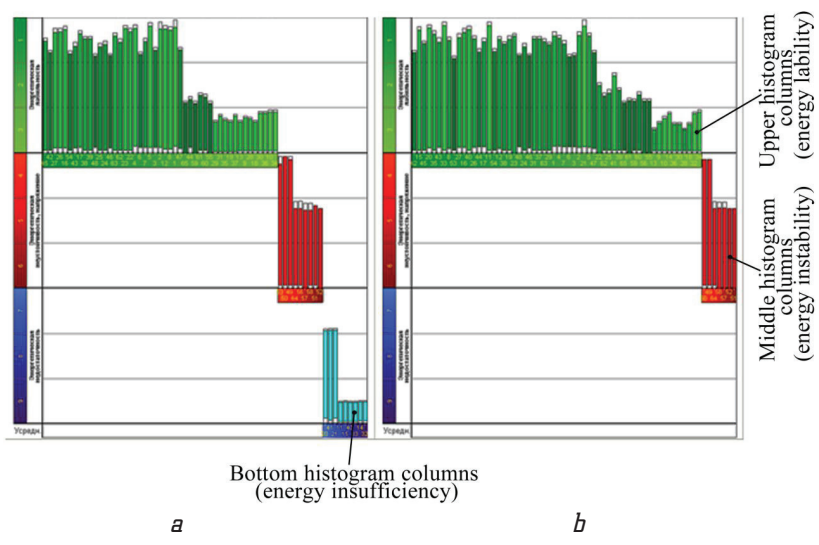

Fig. 12. Windows of the software for «Intera-DiaCor» (Ukraine), reflecting the diagnostics results of the functional state of the patient: $a$ - without the influence of the designed underwear; $b$ - with the influence of the designed underwear 
Comparing the number of organs in different energy states (Fig. 12), it is established that the men's therapeutic and prophylactic underwear has an affect the functional state of the human body.

It should be noted that none of the nine patients with a subclinical course of chronic prostatitis had a seasonal exacerbation, which was regular in previous years.

In a patient who had clinical signs of exacerbation of chronic prostatitis, the period of exacerbation decreased from fourteen days to six, and the patient's improvement was felt on the third day of complex treatment.

Thus, it is established that the use of the developed therapeutic and prophylactic underpants makes it possible to improve the functional state of the men's body with chronic prostatitis, that is, the formed package of materials is rational, and developed AMC is effective and adaptive.

\section{SWOT analysis of research results}

Strengths. Among the strengths of this research, it is necessary to highlight the development and application of the principles of AMC conceptual design, based on the use of energy-information technologies. This allows to selectively choose knitted fabrics, which have a high inertness level to the functional state of the human body. This is the basis for expanding the functionality of men's underwear. In addition to the basic functions, these clothing have additional functions for treatment and prevention of chronic prostatitis. A positive therapeutic and prophylactic effect on patients is ensured by silver plates located on AMC sites according to the BAZ of the lower part of the men's body. Provision of multi-functional clothing with advanced functionality has a positive economic effect by reducing the consumer's money costs and reducing the time spent on medical procedures. The social effect of the work is manifested in improving the health status of men with chronic prostatitis, and, accordingly, improving the quality of their life.

Weaknesses. The weak side of this research is the necessary for specialized software and highly qualified personnel for its application.

Opportunities. The opportunities for further research are to provide different types of clothing with additional functionalities aimed at improving the life quality of a modern person.

Threats. When introducing the object of research into mass production, it is necessary to provide additional time costs associated with the evaluation of the energyinformation impact of materials for AMC, especially with frequent changes in the range of materials and large volumes of production.

Thus, SWOT analysis of research results allows to identify the main directions for the successful achievement of the aim of further research. Among them, ensuring the effectiveness of AMC different assortment at the expense of properties, as well as improving the methodology for assessing the energy-information impact of materials on the functional state of the human body.

\section{Conclusions}

1. Knitted fabrics are selected and justified, which have a high inertness level $\left(k_{I}=0.87 \ldots 0.97\right.$ and $k_{I}=0.88 \ldots 1.00$, respectively) for the functional state of the human body, and are recommended as the basic and lining materials for the manufacture of men's therapeutic and preventive clothing.

2. The technology of joining materials and means of AMC influence is justified. It is determined that with increasing the design thickness of the package of materials by $32 \%$, the thickness of the seam grows by a smaller amount $-28.8 \%$. Thus, the chosen technology of joining materials and means of AMC influence ensures the comfort of the developed AMC during operation.

3. The effectiveness and adaptability of the developed men's therapeutic and prophylactic underwear is estimated through clinical approbation. The improvement of the functional state of the men's organism with chronic prostatitis after the exploitation of the developed AMC for one month is confirmed. According to the results of AMC experimental wearing, it is determined that for $100 \%$ of the respondents the indicators of operational control of all patients does not deteriorate. Evaluation of the psycho-physiological sensation of a person in the developed underwear shows that AMC is comfortable and pleasant for a warm sensation for $100 \%$ of patients. So, the final result of the work is aimed at satisfying the needs of consumers and market requirements. The main economic effect of using the developed AMC is to provide it with additional functions that is expanded the possibilities of its use.

\section{References}

1. Chuprina, N. V. Enerhozberihaiuchi tekhnolohii ekodyzainu u stvorenni suchasnoho odiahu yak produktu industrii mody [Text] / N. V. Chuprina // Visnyk Kyivskoho natsionalnoho universytetu tekhnolohii i dyzainu. - 2013. - № 6 (74). P. 245-253.

2. Deepti, G. Functional clothing - definition and classification [Electronic resource] / G. Deepti // Indian Journal of Fibre \& Textile Research. - 2011. - Vol. 36 (4). - P. 321-326. - Available at: \www/URL: http://hdl.handle.net/123456789/13225

3. Cunha, J. Designing multifunctional textile fashion products classification [Electronic resource] / J. Cunha, A. C. Broega // Autex 2009 World Textile Conference. - 2009. - Available at: \www/URL: https://repositorium.sdum.uminho.pt/ bitstream/1822/19207/3/AUTEX09_JC_CB.pdf

4. Haydon, B. Les nanomatériaux et leur utilisation dans les textiles - Normes. Normalisation interne pour les fabricants et les importateurs canadiens et développements internationaux en matière de normalisation classification [Electronic resource] / B. Haydon // Government of Canada. - 01.05.2017. - Available at: \www/URL: https://www.ic.gc.ca/eic/site/textiles-textiles.nsf/ fra/h tx03226.html

5. Nikolaev, E. L. Adaptation and personality adaptive potential: current research approaches [Text] / E. L. Nikolaev, E. Yu. Lazareva // Vestnik psihiatrii i psihologii Chuvashii. - 2013. № 9. - P. 18-32.

6. Kobylianska, R. M. Monitorynh stanu imunnoi systemy ta efektyvnosti zastosuvannia informatsiinykh imunokorektoriv [Electronic resource] / R. M. Kobylianska, V. Ya. Kobylianskyi // Materialy naukovo-praktychnoi konferentsii z mizhnarodnoiu uchastiu «Suchasni teoretychni ta praktychni aspekty shchodo stratehii rozvytku narodnoi i netradytsiinoi medytsyny», 28-29 zhovtnia 2016 r. - Kyiv, 2016. - P. 68-69. - Available at: \www/URL: http://uanm.org.ua/wp-content/uploads/2016/12/ Print Konferencia Books 1 182A5 281016 li 211016.pdf

7. Bereznenko, M. P. The physical nature of disease and the role of clothing as a factor of healthcare [Text] / M. P. Bereznenko, I. M. Fedotkin, S. M. Bereznenko, O. Y. Yantsalovskyi // Visnyk of Kherson National Technical University. - 2013. № 3. - P. 16-19. 
8. Bereznenko, K. P. Influence of Textile Materials on the Functional State of Human Body - Assessment [Electronic resource] / K. P. Bereznenko, S. M. Bereznenko, M. Pawłowa, O. I. Yantsalovskyi, V. Vlasenko // Towaroznawcze Problemy Jakosci. - 2011. - № 4. - P. 59-65. - Available at: \www/URL: http://bazekon.icm.edu.pl/bazekon/element/bwmeta1.element. ekon-element-000171197633

9. Lushchevska, O. M. Doslidzhennia ekolohichnoi bezpechnosti materialiv dlia vyhotovlennia verkhnoho odiahu [Text] / O. M. Lushchevska, O. I. Yantsalovskyi, S. V. Peteherych, M. P. Bereznenko // Problemy legkoi i tekstilnoi promyshlennosti Ukrainy. - 2012. - № 1 (19). - P. 105-109.

10. Bereznenko, M. P. Enerho-informatsiinyi aspekt funktsionuvannia systemy «Liudyna-odiah-navkolyshnie seredovyshche» [Text] / M. P. Bereznenko, V. I. Vlasenko, O. I. Yantsalovskyi, O. M. Lushchevska // Bulletin of the Kyiv National University of Technologies and Design. - 2011. - № 4. - P. 104-109.

11. About Complex [Electronic resource] // Intera-DiaCor. - Available at: \www/URL: http://www.diacor.com.ua/en/?page=complex

12. Lushchevska, O. M. Rozrobka metodyky doslidzhennia komfortnosti tekstylnykh materialiv [Text] / O. M. Lushchevska, O. M. Troyan, O. I. Yantsalovskyi // Visnyk of Kherson National Technical University. - 2008. - № 6. - P. 151-155.

13. Skrypnyk, Yu. O. Intehralna otsinka komfortnosti tekstylnykh materialiv za elektromahnitnymy pokaznykamy [Text] / Yu. O. Skrypnyk, K. L. Shevchenko, N. P. Suprun, O. A. Vahanov // Bulletin of the Kyiv National University of Technologies and Design. - 2005. - № 1. - P. 104-109.

14. Khammatova, V. V. Manufacture of experimental samples of nanomodified textile materials affect the strength of special purpose clothing [Text] / V. V. Khammatova // Izvestiia vuzov. Tehnologiia tekstil'noi promyshlennosti. - 2016. - № 2 (362). P. 59-65.

15. Rakhimova, S. M. The use of nanosized metal oxides for antimicrobial finish of cotton fabric [Text] / S. M. Rakhimova, A. Vig, B. R. Taussarova, A. Zh. Kutzhanova // Izvestiia vuzov. Tehnologiia tekstil'noi promyshlennosti. - 2015. - № 3 (357). P. 202-205.

16. Shchutska, G. Development and application of the discrete model of multilayered textile materials [Text] / G. Shchutska // Eastern-European Journal of Enterprise Technologies. - 2016. № 6/5 (84). - P. 39-45. doi:10.15587/1729-4061.2016.85784

17. Cho, G. Smart Clothing. Technology and Applications [Text] ed. by G. Cho. - FL, USA: CRC Press, Inc. Boca Raton, 2009. - 287 p. doi:10.1201/9781420088533

18. Ariyatum, B. The future design direction of Smart Clothing development [Text] / B. Ariyatum, R. Holland, D. Harrison, T. Kazi // Journal of the Textile Institute. - 2005. - Vol. 96, № 4. - P. 199-210. doi:10.1533/joti.2004.0071

19. Berglin, L. T. H. Interactive Textile Structures Creating Multifunctional Textiles based on Smart Materials [Electronic resource]: PhD Thesis / L. T. H. Berglin. - Gothenburg, Sweden: Department of Computer Science and Engineering, Chalmers University of Technology, 2008. - Available at: \www/ URL: https://www.diva-portal.org/smash/get/diva2:876879/ FULLTEXT01.pdf

20. Krasniuk, L. V. Prospects for the creation of multifunctional garments based on biologically active points and biologically active zones of the human body [Text] / L. V. Krasniuk, O. M. Troyan, O. Y. Yantsalovskyi, V. S. Torokanets // Visnyk of Kherson National Technical University. - 2016. - № 5. P. 110-115.

21. Skrypnyk, Yu. O. Elektrofiziolohichni metody otsinky komfortnosti odiahu [Text] / Yu. O. Skrypnyk, N. P. Suprun, V. M. Kholodenko // Bulletin of the Kyiv National University of Technologies and Design. - 2005. - № 5. - P. 152-159.
22. Bikbulatova, A. A. Determining the Thickness of Materials in Therapeutic and Preventive Heat-saving Garments [Text] / A. A. Bikbulatova // Izvestiia vuzov. Tehnologiia tekstil'noi promyshlennosti. - 2014. - № 1 (349). - P. 119-123.

23. Buhantsova, L. V. Research on influence of seams parameters on seam thickness of single-layer clothing [Text] / L. V. Buhantsova // Visnyk of Kherson National Technical University. 2016. - № 4. - P. 56-61.

24. Sarhan, T. M. A. Interaction between Sewing Thread Size and Stitch Density and Its Effects on the Seam Quality of Wool Fabrics [Text] / T. M. A. Sarhan // Journal of Applied Sciences Research. - 2013. - Vol. 9, № 8. - P. 4548-4557.

25. Choudhary, A. K. Effect of Some Fabric and Sewing Conditions on Apparel Seam Characteristics [Text] / A. K. Choudhary, A. Goel // Journal of Textiles. - 2013. - Vol. 2013. - P. 1-7. doi:10.1155/2013/157034

26. Zamyshlyaeva, V. V. Research of Influence of Thread Connections on Indicators of Shape Stability Package Clothes [Text] V. V. Zamyshlyaeva, N. A. Smirnova, S. V. Volkova, L. M. Tatarnikova // Izvestiia vuzov. Tehnologiia tekstil'noi promyshlennosti. - 2014. - № 5 (353). - P. 8-12.

27. Dobilaite, V. The influence of mechanical properties of sewing threads on seam pucker [Text] / V. Dobilaite, M. Juciene // International Journal of Clothing Science and Technology. - 2006. Vol. 18, № 5. - P. 335-345. doi:10.1108/09556220610685276

28. Buhantsova, L. The coefficient of seam thickness of multifunctional clothing [Text] / L. Buhantsova // Abstracts of scientific papers XIII International Scientific-Practical Conference: «Actual Problems of Modern Science», Moscow - Astana - Vienna - Kharkov, 28 October 2016. - International Science Center, 2016. - P. 19-21

\section{ФОРМИРОВАНИЕ ПАКЕТА МАТЕРИАЛОВ АДАПТИВНОЙ МНОГОФУНКЦИОНАЛЬНОЙ ОДЕЖДЫ}

В результате аналитических и экспериментальных исследований обоснован выбор пакета материалов для создания адаптивного белья для профилактики хронического простатита. На основании результатов исследования толщины швов, в состав которых входят средства лечебно-профилактического воздействия, выбрана рациональная технология изготовления проектируемого изделия. Подтверждено качество и эффективность разработанного белья путем проведения опытной носки и клинической апробации.

Ключевые слова: адаптивная многофункциональная одежда, толщина шва, энергоинформационное влияние, пакет материалов.

Buhantsova Ludmyla, PhD, Associate Professor, Department of Technology and Design of Garments, Khmelnitsky National University, Ukraine, e-mail: milabunyak@i.ua, ORCID: http://orcid.org/ 0000-0003-3452-4593

Luschevska Olena, PhD, Associate Professor, Department of Technology and Design of Garments, Khmelnitsky National University, Ukraine, e-mail: lenutsas2015@gmail.com, ORCID: http://orcid.org/ 0000-0003-2689-798x

Troyan Oleksandr, PhD, Associate Professor, Department of Technology and Design of Garments, Khmelnitsky National University, Ukraine, e-mail: omtroyan@gmail.com, ORCID: http://orcid.org/ 0000-0003-3339-3659

Krasniuk Larysa, PhD, Associate Professor, Department of Technology and Design of Garments, Khmelnitsky National University, Ukraine, ORCID: http://orcid.org/0000-0003-1429-7178

Yantsalovskyi Oleksandr, Urologist, Khmelnytskyi City Polyclinic № 4, Ukraine, e-mail: topurolog@gmail.com, ORCID: http:// orcid.org/0000-0003-0986-4166 